\title{
THE ACTS OF THE APOSTLES
}

\section{A PLEA FOR AN EARLY DATE.}

THE present paper confines itself strictly to one point in regard to the book of the Acts of the Apostles, namely, the date of its composition ${ }^{1}$. If the date here proposed be established, our attitude towards many of the questions that may be or have been raised about the book will be radically altered. Possibilities which must be kept open, or at least faced and considered, if the Acts was written after A.D. 70 , can be safely set aside if it be once shown that it should rather be dated before the death of St. Paul, or, to speak more precisely, at about the end of the two years' imprisonment at Rome mentioned in Acts xxviii 30.

This is of course not the date adopted by the great majority even of those critics who accept the Lucan authorship of the Acts *. Bishop Lightfoot, in Smith's Dictionary of the Bibleand, somewhat more doubtfully, Mr. Headlam in Hastings' Dictionary-incline to a date after the destruction of Jerusalem. Dr. Sanday speaks of 'circa 80 A.D.' ${ }^{3}$, and this appears to be also Prof. Ramsay's view. I shall speak later on of the argument from the Gospel that has probably appeared decisive to some at least of these critics, and rather begin by enumerating what seem to me to be the difficulties attaching to any date as late as A.D. 70, since it is on these that the case for the earlier date mainly rests.

I. The crucial difficulty is the silence of the Acts as to St. Paul's martyrdom: and it is a difficulty which confronts us from more than one point of view.

1 Since not everything can be proved in the compess of a single short article, the Lucan authorship is assumed, though, as a matter of fact, many of the arguments would not be affected if the reader were to substitute 'the author of the Acts' for each mention of St. Luke.

- Exceptions, however, are Salmon, Introd. to tha N. T., ed. I p. 390, and Blass, Acta apastalonm, pp. 3-5.

Inspiration, p. 449. 
First then in regard to the structure of the Acts as a whole. It has become a commonplace to say that the book shows that its author had an artist's conception as well as an artist's hand, that it is composed on a definite plan with definite aim and definite progress to its end. And on the one view of the date this conception and development is indeed perfectly clear, obvious, and intelligible: but on the other the Acts would only resemble a building out of proportion, badly constructed, and inexplicable. For in investigating the principles of the building we find it is constructed on a framework of the law of Christian life. This law is learnt in the Gospel, and upon it is based the scheme both of the Gospel and the Acts. In both we have an Introduction or Preparation : then an outpouring of the Holy Spirit : this is followed by the body of the work, the active Ministry. This ministry is concluded by a Passion, which is early anticipated ${ }^{1}$, and is narrated at great length : but the Passion is followed by a Resurrection or Deliverances. In all this the Acts corresponds to the Gospel as a whole, but at the same time falls itself into two parts-the Acts of St. Peter (i-xii) and the Acts of St. Paul (xiii-xxviii): and, without interfering with the general scheme, each of these is modelled upon the same idea : Preparation (ch.i; and for Part II ch. xii, cf. xi 27-30 and xii 25): Manifestation of the Spirit (ii I-I3; xiii I-4): Work (ii $14-x i 26$; xiii 4xix 20): Passion and Deliverance (xii; and xix 2I-xxviii). At the end of the first part we have the martyrdom of St. James, but in St. Peter's case an imminent death followed by sudden deliverance. Similarly in St. Paul's case the actual death is wanting, but St. Luke gives what had (at our supposed date of writing) most nearly corresponded to the Lord's Passion-his bondage at Jerusalem, his delivery into the hands of the Gentiles, and the 'going down to the deep' (like Jonah) in the shipwreck. After this escape there is no anticipation of death, but rather an air of optimistic confidence: his light custody and freedom of work at Rome are, as it were, a restoration of life after death.

Now if St. Luke wrote before the death of St. Paul, all this is intelligible and the comparison holds good. But if he wrote

1 Cr. Acts xix 21 , and Luc. ix $5 \mathrm{r}$.

- Acts xxviii roughly corresponds to Luc. Ixiv, and more definitely Acts zxviii 30, 3I, with Luc. xxir 52, 53 . 
after the death of the Apostles the state of the case is entirely altered. He has not only missed in the Acts the obvious parallel to the Passion of the Gospels, but also made it hard for us to discover any plan at the bottom of his narrative. We should be wholly at a loss to understand the reason for the great length and detail of chapters $\mathrm{xx}$-xxviii in relation to the rest of the work. What would be intelligible enough (on almost any theory of the plan of the book) if the author were writing immediately after the conclusion of the period described-since it is always natural for recent events to loom large upon the view-is unintelligible in the case of a retrospect several years later, at a time when St. Paul's arrest and trial at Jerusalem ought surely to have fallen into a subordinate place. St. Luke then, if writing after St. Paul's death, has undoubtedly been guilty of making a false climax : even Prof. Ramsay has to admit that 'the plan of the Acts has been obscured by the want of the proper climax and conclusion '.' But with the evidence of St. Luke's literary power supplied by the Acts itself, we cannot believe that he would have been guilty of such an error in his main conception or have produced so disproportionate a work.

Secondly, there is what we may call the personal point of view.

In the second part of the Acts (ch. xiii-xxviii) St. Paul is the central figure. St. Luke is obviously devoted to him personally, and leads us in his footsteps with an ever increasing interest. From the twentieth chapter (more particularly from xix 21) matters have been working up to a crisis. St. Paul is arrested: we are taken minutely through the first stages of his trial; the end is at hand, his doom is to be decided-and the story suddenly breaks off. What was the fate of St. Paul? There is not a word to say. The martyrdoms of St. Peter and St. Paul must have been to Christians all the world over among the most exciting events of the Church's history: yet St. Luke, writing at or for Rome, keeps silence. There is not only no description of the martyrdom-I shall speak later on of the hypothesis that the account of this was to have followed in a third volume-but there is not even a single anticipatory hint or allusion to the fate of St. Paul. And this is all the more remarkable, because an air of sorrowful presentiment does hang over the last journey to 
Jerusalen 1. But presentiment of what? Not of death at all, but of 'bonds and imprisonment' awaiting the Apostle. No doubt St. Paul's arrest at Jerusalem and delivery 'into the hands of the Gentiles' (xxi II) was a crisis in his life. Yet how much the anticipation of a martyr's death would have heightened the pathos and force of the narrative ${ }^{8}$.

This absence of allusion is especially surprising as we realize the dramatic power of St. Luke. Tradition made him a painter, and certainly he had the painter's power in sketching a vivid scene by a few dramatic touches. His eye is wide open to the significance of details or incidents. He likes to indicate contrasts : the liberality of Joseph Barnabas and the covetousness of Ananias and Sapphira, the deliverance of Peter and the judgement of Herod, are placed side by side. 'The young man Saul' is introduced into the scene of St. Stephen's martyrdom; the historian traces the doctrine of retribution at work in subsequent events. and the words he uses of St. Paul's sufferings continually remind us of the measure dealt by Saul to Stephen. What a complete fulfilment of the doctrine would have been given by the shedding of St. Paul's own blood!

The real difficulty here proved is the absence not so much of deliberate statement as of incidental and, as it were, unintentional allusions. We should have a parallel case if a devoted cavalier and personal attendant of King Charles I, writing about A.D. 1660 a history of the Great Rebellion, should have stopped short at A.D. 1647 without having let drop a hint or a word to suggest the ultimate fate of the king.

II. A similar chain of reasoning will make it probable that the Acts was composed before the end of St. Paul's first Roman imprisonment, if, as we believe, that ended in a trial and acquittal ${ }^{3}$. Just as to have stopped short of the martyrdom would have obscured the main conception of the book, so to have stopped short of the acquittal would have lost an obvious

\footnotetext{
${ }^{1}$ Not, we notice, over the voyage to Rome, and yet here the pathos ought to have been the most intense, if the writer was aware that this journey, far more directly than the journey to Jerusalem, was going to lead to death.

- In the Gospel, which does reach its climax in a Passion preceded by a journey. the dramatic effect is made unmistakeable by direct predictions of the end.

- This acquittal is accepted now even by critics like Harnack and Jalicher, who reject the Pastoral Epistles as a whole.
} 
opportunity for emphasizing one of its subordinate but far from unimportant objects. Rome is the goal of the Acts, and its author brings Paul to Rome. But if the apostle had stood before the Caesar, that was surely a far completer fulfilment of the prophecy that he should bear 'the Name before Gentiles and kings and the children of Israel' (ix 15) than his oration before a mere procurator like Festus and a petty king like Agrippa II (xxvi 2-13). Paul before Caesar would indeed have been a fitting scene for St. Luke's pen and a fitting climax for his work. And if St. Paul had already been successful in his appeal and been set free, how much better that would have served St. Luke's purposes than the declaration of Festus and Agrippa that there was no wrong in the man.

If the later date be correct, St. Luke is guilty of nothing less than a literary crime : he excites all his readers' interest in the fate of St. Paul, and then leaves him without a word as to the conclusion.

More than this, St. Luke becomes actually misleading. He describes the journey up to Jerusalem as a farewell journey. St. Paul says his last words to the Church; he tells the Ephesians that they shall see his face no more. But if St. Paul was liberated and actually visited Ephesus again, St. Luke must have written differently and must have altered the whole complexion of the journey ${ }^{1}$.

These considerations appear to establish at least a prima facie case against any date for the Acts after St. Paul's death or even liberation. It has been sought to meet them by the supposition that St. Luke had in store a third volume which would restore the balance and make all clear. Yet even so the silence of the Acts about St. Paul's fate would still be inexplicable : the charge of disproportion in chapters $\mathbf{x x}$-xxviii would still hold: and this third volume, if it was to have begun with the persecution and martyrdom of the apostles, would still be quite out of analogy with the scheme of the Gospel and Acts.

III. Yet another difficulty lies in the tone of the Acts. A

\footnotetext{
1 Supposing, on the other hand, that St. Paul after his liberation went to Spain and not to the East at all, the words could stand: but, in this case, why the silence about ' the boundary of the West,' when the work there would have been so fitting a fulfilment of the command to preach 'unto the end of the earth' (i 8)?
} 
note of joy and an air of peace pervade the whole book. Persecutions there had been in plenty, but the writer is an optimist and sees how good has been brought out of evil. He has discovered a law that persecution is followed by a period of peace and progress ${ }^{1}$, and when we come to the end peace and joy are triumphant. The apostle works at Rome without hindrance, and the optimist writer can take a tranquil retrospect of the past. Now could this tone have been possible after the martyrdom of the apostles? The great personal affection of St. Luke for St. Paul is obvious. Could he, after St. Paul's bloody death, sit down in his study and take a calm, peaceful, even joyful, view of the past? No doubt an optimistic temperament and strong religious faith will help much, but they cannot altogether suppress personal emotion.

Nor is it a question here of St. Paul's death only. It is the situation of the Church at large which must have rendered impossible such a quiet retrospect. The cruel and bloody persecution of the Church at Rome under Nero must have been a greater disaster than the scattering of the Church at Jerusalem after the death of Stephen. It must have affected the whole Church. Hitherto there had been persecutions, but on a limited scale, with few deaths. Now the wholesale slaughter under Nero must have marked an epoch in the relations of the Church and the Empire. The Apocalypse gives us a faithful picture of the feeling of Christians towards the Babylon drunk with the blood of saints and martyrs. St. Luke's description in chapter xxviii $3^{\circ}, 3^{\text {I }}$ would not only have been difficult to write but actually misleading.

If, then, St. Luke wrote subsequently to the Neronian persecution, it could only have been when the lapse of some years had restored peace to the Church, had healed its wounds, and had mitigated the personal grief for the loss of the apostle. This could hardly have been before 'circa $80 \mathrm{~A}$. D.'

Such a long interval has, however, its special difficulties.

A characteristic of the Acts is the remarkable fidelity of its pictures to the contemporary situation. This has, for instance,

1 Compare iv 5-22, followed by $23^{-31}$ (esp $\left.3^{1}\right)$; 4 40 by 41, 42; vi 8-viii 3 by viii 4-xi 26 (esp. ix 31 ); xii $1-17$ by 24 ; xiii 50 by 52 ; xiv 2 by 3 (esp. Beran taxt); xiv 5 by 7 ; xiv 19 by 21 ; xv 2-5 by 30-33 (preas).

VOL. 1 . 
been strikingly brought out by Professor Ramsay in relation to the cities of Asia Minor. But the most noteworthy illustration is given by the early history of the Church at Jerusalem. There we find reproduced with exactness the condition of Jerusalem between 30 and 40 A.D., the relations of Pharisees and Sadducees, of Gamaliel and the high-priestly party, of Jews and Hellenists; the attitude of different parties to the Church; the simplicity of the Christian society, which appears as a continuance of the band of disciples in the Gospel, the place of the Lord being now filled by the apostles, and the whole body being nothing more on the outside than a Jewish alpe $\sigma$ ts, ' the Nazarenes.' These conditions passed rapidly away; and if it was still possible for St. Luke, on a visit to Palestine and Jerusalem in $54-56$ A.D., to realize the phenomena of Church life 'from the beginning,' that was just because the local church at Jerusalem, maintained its original character ( $x x i 17-26$ ) in contrast to the speedy development which was taking place elsewhere. But after A. D. 70 and the end of the Church at Jerusalem, it must have been difficult in the extreme to draw such a vivid picture of Jewish politics; and great as were St. Luke's gifts it would argue a literary self-control which is almost inconceivable that the destruction of Jerusalem should nowhere have visibly affected his retrospect. But the reader rises from the book with the impression that the holy city is still standing, the Templeservice still maintained with earnest zeal (xxvi 7), and the Church still comprising at Jerusalem myriads of Jews zealous for the law (xxi 20). Yet how close was the bearing of the great catastrophe on the events recorded in St. Luke's history. It was the divine settlement of the controversy about the Law which had vexed the Church; it was the divine refutation of the Jewish charges against St. Stephen; it was the divine retribution for their persecution of the Church (cf. I Thess. ii 16); but not a dramatic hint is given or word uttered on any of these occasions.

Enough has been said as to St. Luke's silence over the death of St. Paul and the fall of Jerusalem. But even these, crucial as they were, were not the only events of stirring interest in the period 60-80 A. D. And the third volume theory, though it will explain the ending of the narrative at circa $60 \mathrm{~A}$. D., will not explain the entire absence of any allusion to the events of the 
next twenty years. Not a hint in the Acts would enable a modern critic to conjecture, e.g., the subsequent movements and fate of St. Peter, St. James the Lord's brother, or St. John, or the history of the Church at Jerusalem, at Ephesus, at Rome. How different it is in the case of St. John's Gospel. We can tell at once that St. Peter has been already girded and carried 'whither he would not,' and that the great age of St. John is arousing speculation among the brethren ${ }^{1}$.

IV. A late date not only affects the artistic structure of the Acts, but its aim and object. No doubt the main motive still held good, viz. to continue the record of 'what Jesus began to do and to teach' (i. I) in the Church. But besides this there were certainly subsidiary aims in the writer's mind.

(I) Among these, very obvious is the apologia for Christianity to the Roman authorities. And as such it would serve excellentlybefore 64 A.D. But Nero's persecution altered the whole relation of Church and Empire. That was settled from A. D. 64; the Emperor had declared war; Christianity had become a religio illicita ; and St. Luke's arguments were thrown away. For his presentation of the origin and growth of Christianity was an appeal to authorities who would be ignorant of, and indifferent to, the facts of the case, and whose attitude was uncertain. Hitherto in individual cases they had asserted the innocence or harmlessness of the Christian teachers. But an appeal had been made to Caesar at Rome. At Rome and in the imperial court Jewish influence was strong. Something was wanted on the Christian side to counteract that influence : at least the judgesthe public and the magistrates-ought to have a fair, impartial statement of the facts from the Christian point of view. And if St. Luke was contemplating a history, here was a reason for hurrying forward its composition and publication.

(2) The Acts is a vindication of the catholicity of the Church, and a proof of the true communion between Jewish and Gentile brethren But in 80 A.D. no vindication of the existence of 'Churches of the Gentiles' was necessary. The question as to Jew and Gentile in the Church had been settled by facts. The

1 It may of course be only an accident that in the Goopel and Acts we meet with the names of Augustus, Tiberius, and Clendius; Nero appeass only as 'Caesar'; and no later emperor is alluded to. 
temple and its ritual had passed away, and the Church was predominantly Gentile. The distinctions between Hebrew, Jew, Hellenist, proselyte, Greek, and Gentile, were merged in the simple division between Jew and Christian, and their very meaning was being forgotten ${ }^{1}$.

(3) If St. Luke was anxious to vindicate the apostolate of St. Paul as equal to that of St. Peter, and yet prove the true unity between them-what better proof could he have had than the dramatic picture of the two brother Apostles martyred at Rome, showing that ' in death they were not divided '?

$V$. There remain the literary questions. (I) It is clear that the writer has not used our Epistles of St. Paul as his authorities. They can be fitted in, but there was no special desire of illustrating or even harmonizing with them. This is evident from some apparent discrepancies, especially between the Acts and Galatians. If St. Luke wrote at a date when the Epistles were the public property of the Church and widely read, we cannot imagine his leaving such inconsistencies in their present form. But if he wrote before St. Paul's death all is clear. (a) The letters of St. Paul were numerous, our Epistles had not won their pre-eminent position, and as yet they were the private property of the Churches to whom they were addressed. St. Luke, instead of letters, had the living voice of the Apostle for his authority; and it is no fancy to trace a resemblance of diction between the latter part of the Acts and the Pastoral Epistles. (b) St. Luke was writing at a time when the Epistle to the Galatians was not yet widely circulated. That Epistle contained the record of St. Paul's ' secret history' poured out to his apostate children. But St. Luke was writing for the Church at large, and gives, so to speak, the view from outside, the official report, what had transpired and had been made public. Secret conferences, secret motives and ideas in St. Paul's mind, may have been known to him, but they were private property as it were, suitable for an autobiography rather than for a book of 'Acts of Apostles.' St. Luke was addressing the general church public, who neither knew St. Paul's inner

1 We might also notice that the Acts was written at a time when the question of John the Baptist's Disciples and Baptism was still a practical matter of some importance (rviii 24-xix 7). 
history, nor had any claim to know it. The position of the Acts would be very much that of a history of the Tractarian movement written before the publication of Newman's Apologia and the letters of Pusey and Keble.

(2) Critics in admitting the early date of many of the New Testament writings are recognizing the early development of Christian literature. Certainly the Epistles to the Thessalonians, Corinthians, Galatians, and Romans, all written before A. D. 54 or 56, show it in a matured condition. St. Peter's first Epistle must have been written before A. D. 64 or 65 , St. James' before 62. The conditions of the synoptic problem show that written Gospel sources must go back to a very early date even if we do not assign the first two canonical Gospels to the decade 60-70 A. D. ${ }^{1}$ Why then should St. Luke's writings be postponed till about A.D. 80? The most favourable opportunity for collecting his information must have been the two years at Caesarea, A. D. $54-56$ (or 58-60), and the time when he enjoyed the society of St. Paul : at Rome, during the two years of the first imprisonment, A.D. 57-59 (or 6I-63), he had leisure for the composition. The need for 'certain and accurate information' (Luc. i 4) must have been great. Why then twenty years' delay?

VI. Lastly, we have the problem of the text of the Acts. A composite work like the Acts must have involved much revision and rewriting. Of this process we find, I believe, evident traces or relics in the Bezan text, which seems to represent what we should call 'advance-sheets' suffered by St. Luke to pass into circulation among the Roman Christians in answer to their impatient curiosity. But the Acts never did receive the last touches. Even in the form of the Neutral text-taking that to be the text as St. Luke left it-there remains in places an unevenness and obscurity which we feel that his skilled hand would never have allowed to appear in the published form? ${ }^{2}$. If this be the case, the Acts never was really 'published' by the author, and consequently there was no final definite text. Some explanation of this

\footnotetext{
1 The Acts itself may be thought to suggest that it was written at a time when the chief authority for the Gospel history was still oral tradition: ef. Xx 3j, 'the words of the Lord Jesus.'

- Compare e.g. V J2-15; xii 25 (els Tepouradth); xiii t3, 43; xv 33, to; xvi 19, 20 (sce Ramsay, l.c. p. 217); xvii 8, 9, 13 ; xviii 18; xx 3-5; xrvii 9-1 2.
} 
sort is necessary to account for the phenomena of the diversities of text which are so unique in the case of the Acts.

But if the actual publication never came about, what was the reason? May it not have been the persecution itself? That catastrophe, which must for the moment have shattered St. Luke's optimistic view and clouded the tranquil prospect, would at least have taken from him the heart to rewrite his history under the new conditions, even if it did not close his career by martyrdom.

These arguments are no doubt largely subjective; and their full force can perhaps only be felt by one who has studied the Acts with deep and affectionate sympathy. But taken together they leave a strong conviction that in the Acts we have the work of one who was writing at Rome about A.D. 60 by the side of St. Paul in his imprisonment; who, having leisure to review the past, felt the desire to leave to the Christian body some sure record of these things before the actors in them passed away, and to present both to Jews and Romans a fair statement of the case about St. Paul, entirely uncertain himself as to the final result save for the calm confidence inspired by experience of the past.

Against this-the natural impression given by the Acts itselfI know of but one solid argument, viz. that because of the variations in the Lord's prophecy of the destruction of Jerusalem ${ }^{1}$ the Gospel of St. Luke must have been written after A.D. 70 with a knowledge of the actual facts of the siege, and the Acts therefore later still. The differences are : the omission by St. Luke (xxi 20) of the words let him that readeth understand; the substitution of Ferusalem compassed with armies, \&c. for the abomination of desolation; the omission of the immediately of Matt. Xxiv 29; and the addition of one or two details in xxi $20-25$, not to speak of the second and still more detailed picture in $\mathrm{xix} 43,44$.

Now (i) prophecy apart, it is certain that the Christians were expecting some disaster to befall Jerusalem: St. Paul wrote I Thess. ii 16 as early as 49 or 50 A.D.

(ii) Writing for Gentile readers at Rome, St. Luke translates the imagery of the Old Testament into ordinary language : naturally too he omits

\footnotetext{
1 Luc. xxi 20-25 compared with Mt. xxiv I5-29, Mc. xiii 14-24: see also Luc. xix $43,44$.
} 
the warning to flee. Similarly, but conversely, St. Matthew has emphasized the Jewish point of view by adding the mention of Daniel the prophet and substituting the holy place for the original phrase where it ought not. It is doubtful if the immediately of Matt. xxiv 29 is original, for it is absent from St. Mark; but in any case both St. Mark and St. Luke retain the connexion And there shall be signs with no more hint of an interval than in St. Matthew. (iii) The expressions used by St. Luke are quite general, and describe the ordinary features of the fall and capture of a city : (a) armies surround Jerusalem xxi 20, (b) cast a bank about it xix $43,(c)$ level it with the ground xix $44,(d)$ the inhabitants are slain with the sword or carried captive xxi 24, (e) Jerusalem is trodden under foot of the Gentiles xxi 24. Such a fate Jerusalem had already experienced more than once. And in fact all these expressions can be paralleled from the Old Testament ${ }^{1}$ : in Westcott and Hort (c) and (e) are printed in quotation type. (v) Lastly, no detail is given which would be specially characteristic of the final fall of Jerusalem. There is no prophecy of the presence of Titus, the obstinate resistance, the internecine strife within the city, the famine and its attendant horrors ${ }^{2}$, the burning of the Temple, or the fate of the rebel leaders.

That difficulties, sometimes real difficulties, may still be found in the Acts if the thesis of this paper finds favour, it is not necessary to deny. But as appreciation of the situation of the early Church grows greater the difficulties grow less. The Church then was very much as it is now : it embraced wide differences of character and personality, of theology and views, of education and learning. And in literature too there are differences between history and autobiography, differences in each writer's aim, differences in the public he appeals to, ample enough to account for any residuum of inconsistency or contradiction between the Acts and other authorities.

R. B. RACKHAM.

1 See Is. Ixix 3, 2xxvii 33 ; Jer, vii 34, xx 4; I Kings viii 46 ; Is. v 5 : Zech. xii 3 ; I Mace. iv 60; Pa crexvi 9, lrxix 1; Dan. viii sa St. Hatthew (xxiv 2) and St. Mark (riii 2) themselves specify the detail that not one stone ahall be left upon another.

- Though St. Luke would have had precedent in the O. T. for the detail of ating finst recorded by Josephus : cf. Jeremiah xix $q$ 